\title{
OPEN Effects of solid oxygen fertilizers and biochars on nitrous oxide production from agricultural soils in Florida
}

\begin{abstract}
Tanumoy Bera ${ }^{1,2}$, Kanika S. Inglett ${ }^{2} \&$ Guodong D. Liv ${ }^{1 \bowtie}$
Elevated levels of nitrous oxide $\left(\mathrm{N}_{2} \mathrm{O}\right)$ emissions are a matter of concern in agricultural soils especially when flooding (hypoxic conditions) results from over irrigation or frequent rains. This study is the first to report the use of two solid oxygen fertilizers (SOFs, calcium peroxide and magnesium peroxide) to reduce $\mathrm{N}_{2} \mathrm{O}$ production in mineral and organic soils amended with $\mathrm{N}$ fertilizer in a short-term laboratory incubation besides two biochars. In general, organic soil had greater $\mathrm{N}_{2} \mathrm{O}$ production than mineral soil. Soils amended with nitrogen fertilizer exhibited increased $\mathrm{N}_{2} \mathrm{O}$ production, by 74 times in mineral soil and 2 times in organic soil. Both solid oxygen fertilizers in mineral soil (98-99\%) and calcium peroxide in organic soil (25\%) successfully reduced $\mathrm{N}_{2}$ O production than corresponding $\mathrm{N}$ fertilized treatments. Additionally, a greater level of available nitrate- $\mathrm{N}\left(52-57\right.$ and $225 \mathrm{mg} \mathrm{kg}^{-1}$ in mineral and organic soil, respectively) was recorded with the solid oxygen fertilizers. Corn residue biochar with $\mathrm{N}$ fertilizer increased $\mathrm{N}_{2} \mathrm{O}$ production in mineral soil but decreased in organic soil, while pine bark biochar with $\mathrm{N}$ did not affect the $\mathrm{N}_{2} \mathrm{O}$ production in either soil. Depending on soil, appropriate SOFs applied were able to reduce $\mathrm{N}_{2} \mathrm{O}$ production and maintain greater nitrate-N levels in flooded soil. Thus, solid oxygen fertilizers can potentially be used as an effective way to reduce $\mathrm{N}_{2} \mathrm{O}$ emission from hypoxic soil in agricultural production systems.
\end{abstract}

Nitrous oxide $\left(\mathrm{N}_{2} \mathrm{O}\right)$ is a long-lasting (an atmospheric half life of 114 years) major greenhouse gas (GHG) with 298 times greater global warming potential than carbon dioxide $\left(\mathrm{CO}_{2}\right)^{1}$. Recent studies have reported significant increase in atmospheric $\mathrm{N}_{2} \mathrm{O}$ concentration from 270 to $330 \mathrm{ppb}^{2}$. Higher contribution of $\mathrm{N}_{2} \mathrm{O}$ is from the agriculture sector ${ }^{3}$ where emissions are high due to increased production and higher emissions. These are commonly observed during landuse changes, soil management, inappropriate use of nitrogenous fertilizer, livestock rearing, and handling of manure. $\mathrm{N}_{2} \mathrm{O}$ production in soils is primarily driven by heterotrophic denitrifying microorganisms under hypoxic and anaerobic conditions ${ }^{4}$. In addition to denitrification, several other processes can also contribute to $\mathrm{N}_{2} \mathrm{O}$ production including nitrification, chemo-denitrification, and reaction between nitrite and hydroxylamine $e^{4}$. Among the factors that affect the production of $\mathrm{N}_{2} \mathrm{O}$ are soil aeration, compaction, temperature, organic matter, $\mathrm{pH}$, carbon $(\mathrm{C})$ to nitrogen $(\mathrm{N})$ ratio $(\mathrm{C} / \mathrm{N})$, available $\mathrm{N}$ and moisture content ${ }^{4-6}$. Precipitation has been shown to trigger soil $\mathrm{N}_{2} \mathrm{O}$ production that is episodic in nature ${ }^{7,8}$. Heavy rain events often cause flooding or create situations of standing water on the lowland soil surface leading to low $\mathrm{O}_{2}$ availability and lower redox potential. Presence of available carbon (C) and $\mathrm{N}$ in these conditions can stimulate $\mathrm{N}_{2} \mathrm{O}$ production through heterotrophic denitrification ${ }^{9-13}$.

In Florida, USA, sudden abnormal rains and hurricanes are common and can cause immediate waterlogging, which damages crops, especially vegetables due to stress related to low oxygen availability in soil ${ }^{14}$. Li et al. ${ }^{15}$ reported losses of approximately \$77 million and \$13 million in the Florida vegetable industry due to Hurricane Irene in 1999 and an excessive precipitation in 2000, respectively. Heavy rainfall can create water logging in Florida soils which is conducive to greater $\mathrm{N}_{2} \mathrm{O}$ emissions, thus increasing environmental hazards and decreasing $\mathrm{N}$-use efficiency. The predicted changes in precipitation patterns throughout the world ${ }^{16-18}$ have further exacerbated this issue. In addition to soil saturation, $\mathrm{N}$ fertilization is also a measurable cause of $\mathrm{N}_{2} \mathrm{O}$ emission from agricultural soil ${ }^{6}$. In Florida, $224 \mathrm{~kg} \mathrm{ha}^{-1} \mathrm{~N}$ is recommended for most vegetable crops ${ }^{19}$. Thus, these highly

${ }^{1}$ Horticultural Sciences Department, University of Florida, 1253 Fifield Hall, 2550 Hull Road, PO Box 110690, Gainesville, FL 32611, USA. 'Soil and Water Sciences Department, University of Florida, Gainesville, FL 32611, USA. ${ }^{\circledR}$ email: guodong@ufl.edu 


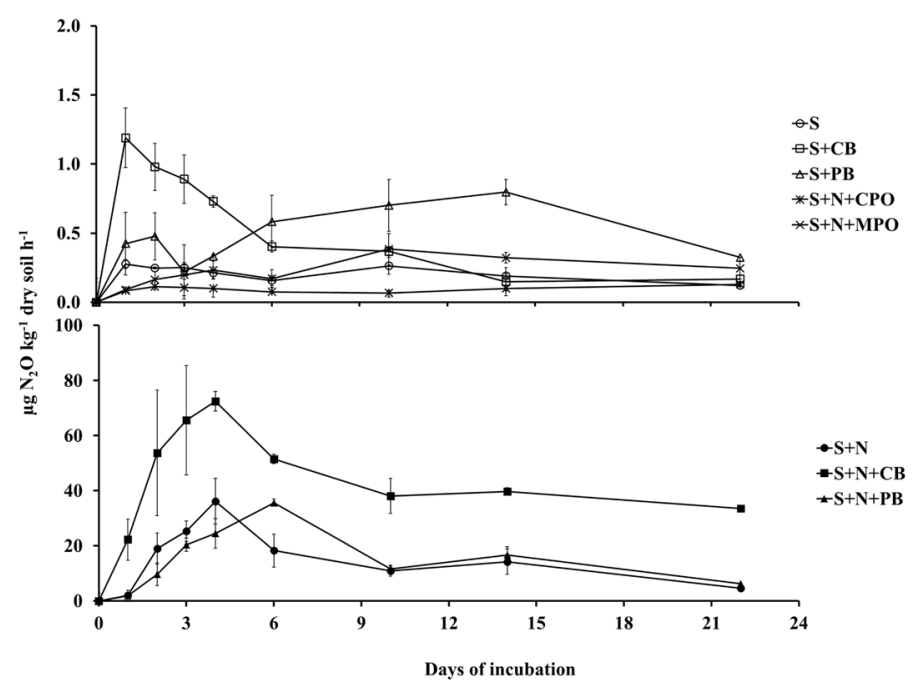

Figure 1. $\mathrm{N}_{2} \mathrm{O}$ production rate over the incubation period from mineral soil (MS). $\mathrm{S}=\mathrm{Control}$ soil only; $\mathrm{S}+\mathrm{N}=$ Control soil with $\mathrm{N}$ fertilizer; $\mathrm{S}+\mathrm{CB}=$ Control soil with corn residue biochar; $\mathrm{S}+\mathrm{CB}+\mathrm{N}=\mathrm{Control}$ soil with corn residue biochar and $\mathrm{N}$ fertilizer; $\mathrm{S}+\mathrm{PB}=$ Control soil with pine bark biochar; $\mathrm{S}+\mathrm{PB}+\mathrm{N}=\mathrm{Control}$ soil with pine bark biochar and $\mathrm{N}$ fertilizer; $\mathrm{S}+\mathrm{N}+\mathrm{CPO}=$ Control soil with $\mathrm{N}$ fertilizer and calcium peroxide; $\mathrm{S}+\mathrm{N}+\mathrm{MPO}=\mathrm{Control}$ soil with $\mathrm{N}$ fertilizer and magnesium peroxide. Bar represents standard error, $\mathrm{n}=3$.

$\mathrm{N}$ fertilized soils possess a greater potential to produce and emit $\mathrm{N}_{2} \mathrm{O}$ in hypoxic condition through heterotrophic denitrification.

To alleviate the $\mathrm{N}_{2} \mathrm{O}$ production, the uses of biochar have been investigated. Biochar is a heterogeneous carbonaceous material produced by pyrolyzing agricultural residues, animal manures, wood waste, city garbage, etc. at different temperature ${ }^{20}$ and has been used for environmental and soil management. The high recalcitrant aromatic $\mathrm{C}$ content of biochar has a mean residence time of $10^{2}$ to $10^{7}$ years ${ }^{21,22}$ and therefore tends to increase the soil carbon $(\mathrm{C})$ stock and crop yield ${ }^{23-26}$. Biochar amended soils have shown to increase plant available nutrients, increased $\mathrm{pH}$ in acidic systems, affect water content, lower bulk density, and reduce aluminum toxicity ${ }^{26,27}$. Besides increasing crop growth and $\mathrm{C}$ sequestration, biochar was found to play a direct role in reducing $\mathrm{N}_{2} \mathrm{O}$ emissions. Variable effect of different kinds of biochars in soils with varying organic matter content has been reported ${ }^{28-31}$. Cayuela et al..$^{32}$ reviewed 261 experimental treatments covering 30 peer-reviewed publications and proposed biotic and abiotic mechanisms behind the role of biochar influencing $\mathrm{N}_{2} \mathrm{O}$ emission from soil. Though the exact mechanism by which biochar reduces $\mathrm{N}_{2} \mathrm{O}$ production in soil is still unclear, the interactions between biochar properties, soil, and the sources and the chemical nature of $\mathrm{N}$ fertilizers appear to be the major controlling factors $\mathrm{s}^{30-33}$. Another strategy to reduce $\mathrm{N}_{2} \mathrm{O}$ production within saturated soils is to increase the redox potential to inhibit heterotrophic denitrification. Solid oxygen fertilizers (SOFs) such as magnesium peroxide $\left(\mathrm{MgO}_{2}\right)$, carbamide peroxide $\left(\mathrm{CH}_{6} \mathrm{~N}_{2} \mathrm{O}_{3}\right)$, and calcium peroxide $\left(\mathrm{CaO}_{2}\right)$ have been shown to alleviate the hypoxic (low-oxygen stress) condition in flooded soils by increasing the redox potential ${ }^{17,34}$. Although SOFs have been reported to reduce hypoxic stress of plants, their role in reducing the anoxic condition in soil has not been investigated widely. Therefore, application of biochars or SOFs may provide an avenue to reduce heterotrophic denitrification loss of $\mathrm{N}_{2} \mathrm{O}$ from soil in waterlogged condition. The objective of this study was to evaluate the effects of SOFs and biochar on $\mathrm{N}_{2} \mathrm{O}$ production and emissions from two agricultural soils with considerably different organic $\mathrm{C}$ content with or without $\mathrm{N}$ fertilizer application.

\section{Results}

$\mathbf{N}_{2} \mathrm{O}$ production rate. Net nitrous oxide production (henceforth only production) rate was greater in the organic soil (OS) treatments than in the corresponding mineral soil (MS) treatments at all sampling events during incubation (Figs. 1,2). The greatest $\mathrm{N}_{2} \mathrm{O}$ production rate in MS and OS soil ranged 67-73 and 181-237 $\mu \mathrm{g}$ $\mathrm{N}_{2} \mathrm{O} \mathrm{kg}^{-1}$ soil $\mathrm{h}^{-1}$, respectively. In MS, there were two distinguishable groups among the treatments regarding $\mathrm{N}_{2} \mathrm{O}$ production rate (Fig. 1). All $\mathrm{N}$ fertilizer treatments had greater $\mathrm{N}_{2} \mathrm{O}$ production rates, with a peak of $73 \mu \mathrm{g}$ $\mathrm{N}_{2} \mathrm{O} \mathrm{kg}^{-1}$ soil h${ }^{-1}$ with corn residue biochar and $\mathrm{N}$ fertilizer $(\mathrm{S}+\mathrm{CB}+\mathrm{N})$, than the other treatments either without $\mathrm{N}$ fertilizer or with SOFs. Control soils without $\mathrm{N}$ fertilizer $(\mathrm{S})$, with corn residue biochar $(\mathrm{S}+\mathrm{CB})$, and with pine bark biochar $(\mathrm{S}+\mathrm{PB})$ or control soil with $\mathrm{N}$ fertilizer and calcium peroxide $(\mathrm{S}+\mathrm{N}+\mathrm{CPO})$ and magnesium peroxide $(\mathrm{S}+\mathrm{N}+\mathrm{MPO})$ exhibited rates of $\mathrm{N}_{2} \mathrm{O}$ production ranging from 0.1 to $1.2 \mu \mathrm{gg}^{-1} \mathrm{~h}^{-1} \mathrm{~N}_{2} \mathrm{O}$. Contrary to MS, all the treatments in OS recorded peak $\mathrm{N}_{2} \mathrm{O}$ production rates in the range of $80-237 \mu \mathrm{g} \mathrm{kg}^{-1} \mathrm{~h}^{-1} \mathrm{~N}_{2} \mathrm{O}$. There were also differences in time to attain peak $\mathrm{N}_{2} \mathrm{O}$ production rate among the treatments in the two soils. In MS soil, $\mathrm{S}, \mathrm{S}+\mathrm{CB}$ and $\mathrm{S}+\mathrm{PB}$ produced the greatest amount of $\mathrm{N}_{2} \mathrm{O}$ on the first and second day after beginning of incubation before leveling off. Interestingly, the soil with $\mathrm{N}$ fertilizer and $\mathrm{CPO}$ had similar $\mathrm{N}_{2} \mathrm{O}$ production throughout the incubation, while $\mathrm{S}+\mathrm{N}+\mathrm{MPO}$ recorded greatest $\mathrm{N}_{2} \mathrm{O}$ production rate 10 days after incubation. The control soil with $\mathrm{N}$ fertilizer $(\mathrm{S}+\mathrm{N})$ and $\mathrm{S}+\mathrm{CB}+\mathrm{N}$ treatments reached the peak $\mathrm{N}_{2} \mathrm{O}$ production rate four 


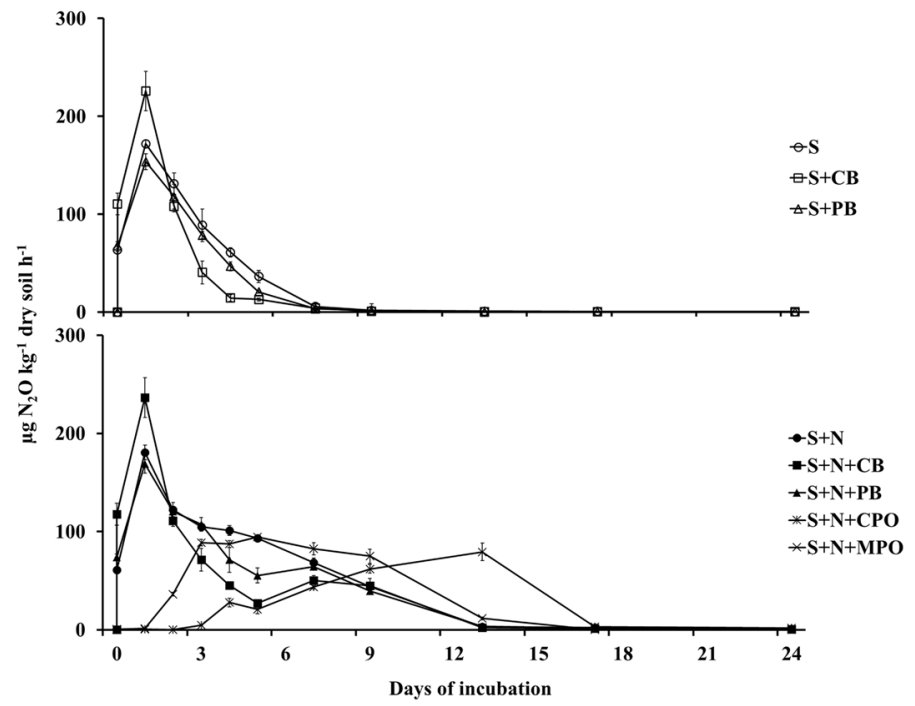

Figure 2. $\mathrm{N}_{2} \mathrm{O}$ production rate over the incubation period from organic soil (OS). $\mathrm{S}=$ Control soil only; $\mathrm{S}+\mathrm{N}=$ Control soil with $\mathrm{N}$ fertilizer; $\mathrm{S}+\mathrm{CB}=$ Control soil with corn residue biochar; $\mathrm{S}+\mathrm{CB}+\mathrm{N}=\mathrm{Control}$ soil with corn residue biochar and $\mathrm{N}$ fertilizer; $\mathrm{S}+\mathrm{PB}=$ Control soil with pine bark biochar; $\mathrm{S}+\mathrm{PB}+\mathrm{N}=\mathrm{Control}$ soil with pine bark biochar and $\mathrm{N}$ fertilizer; $\mathrm{S}+\mathrm{N}+\mathrm{CPO}=$ Control soil with $\mathrm{N}$ fertilizer and calcium peroxide; $\mathrm{S}+\mathrm{N}+\mathrm{MPO}=\mathrm{Control}$ soil with $\mathrm{N}$ fertilizer and magnesium peroxide. Bar represents standard error, $\mathrm{n}=3$.

\begin{tabular}{|l|c|l|l|l|l|l|}
\hline \multirow{2}{*}{} & \multicolumn{2}{|l|}{$\begin{array}{l}\text { Cumulative } \mathbf{N}_{2} \text { O production }(\mu \mathrm{g} \\
\mathbf{k g}^{-1} \text { dry soil) }\end{array}$} & \multicolumn{2}{l|}{ MBC $\left(\mathbf{m g ~ k g}^{-1}\right.$ dry soil $)$} & \multicolumn{2}{l|}{ MBN $\left(\mathbf{m g ~ k g}^{-1} \mathbf{d r y}\right.$ soil $)$} \\
\cline { 2 - 7 } & MS & OS & MS & OS & MS & OS \\
\hline S & $104 \pm 2.8^{\mathrm{c}}$ & $12,027 \pm 874^{\mathrm{d}}$ & $87 \pm 15.0^{\mathrm{a}}$ & $1007 \pm 65^{\mathrm{a}}$ & $3.2 \pm 0.50^{\mathrm{bc}}$ & $54 \pm 16.0^{\mathrm{abc}}$ \\
\hline $\mathrm{S}+\mathrm{N}$ & $7705 \pm 548.0^{\mathrm{b}}$ & $23,757 \pm 352^{\mathrm{a}}$ & $88 \pm 11.5^{\mathrm{a}}$ & $850 \pm 103^{\mathrm{ab}}$ & $2.6 \pm 0.27^{\mathrm{bc}}$ & $31 \pm 6.3^{\mathrm{bc}}$ \\
\hline $\mathrm{S}+\mathrm{CB}$ & $210 \pm 10.7^{\mathrm{c}}$ & $8980 \pm 554^{\mathrm{d}}$ & $71 \pm 5.8^{\mathrm{ab}}$ & $552 \pm 35^{\mathrm{b}}$ & $3.8 \pm 0.46^{\mathrm{ab}}$ & $56 \pm 9.7^{\mathrm{abc}}$ \\
\hline $\mathrm{S}+\mathrm{CB}+\mathrm{N}$ & $23,185 \pm 1487.3^{\mathrm{a}}$ & $18,279 \pm 623^{\mathrm{bc}}$ & $59 \pm 4.8^{\mathrm{abc}}$ & $578 \pm 62^{\mathrm{b}}$ & $5.6 \pm 0.70^{\mathrm{a}}$ & $67 \pm 2.8^{\mathrm{ab}}$ \\
\hline $\mathrm{S}+\mathrm{PB}$ & $29 \pm 16.0^{\mathrm{c}}$ & $9936 \pm 619^{\mathrm{d}}$ & $44 \pm 5.2^{\mathrm{bc}}$ & $635 \pm 120^{\mathrm{ab}}$ & $2.6 \pm 0.37^{\mathrm{bc}}$ & $61 \pm 5.2 \mathrm{a}^{\mathrm{b}}$ \\
\hline $\mathrm{S}+\mathrm{PB}+\mathrm{N}$ & $8619 \pm 189.4^{\mathrm{b}}$ & $20,629 \pm 1210^{\mathrm{abc}}$ & $46 \pm 3.8^{\mathrm{bc}}$ & $823 \pm 71^{\mathrm{ab}}$ & $3.8 \pm 0.32^{\mathrm{ab}}$ & $83 \pm 13.3^{\mathrm{a}}$ \\
\hline $\mathrm{S}+\mathrm{N}+\mathrm{CPO}$ & $51 \pm 6.8^{\mathrm{c}}$ & $17,802 \pm 1019^{\mathrm{c}}$ & $22 \pm 2.4^{\mathrm{c}}$ & $415 \pm 119^{\mathrm{b}}$ & $1.8 \pm 0.11^{\mathrm{c}}$ & $15 \pm 3.6^{\mathrm{c}}$ \\
\hline $\mathrm{S}+\mathrm{N}+\mathrm{MPO}$ & $141 \pm 5.5^{\mathrm{c}}$ & $22,073 \pm 1014^{\mathrm{ab}}$ & $30 \pm 7.7^{\mathrm{c}}$ & $490 \pm 78^{\mathrm{b}}$ & $1.2 \pm 0.11^{\mathrm{c}}$ & $30 \pm 7.3^{\mathrm{bc}}$ \\
\hline
\end{tabular}

Table 1. Total $\mathrm{N}_{2} \mathrm{O}$ production, microbial biomass $\mathrm{C}(\mathrm{MBC})$ and microbial biomass $\mathrm{N}(\mathrm{MBN})$ (mean \pm standard error, $\mathrm{n}=3$ ) in two studied soils [organic soil (OS) and mineral soil (MS)] as influenced by biochar and soil oxygen fertilizers with or without $\mathrm{N}$ at the end of incubation. $\mathrm{S}=\mathrm{Control}$ soil only; $\mathrm{S}+\mathrm{N}=$ Control soil with $\mathrm{N}$ fertilizer; $\mathrm{S}+\mathrm{CB}=\mathrm{Control}$ soil with corn residue biochar; $\mathrm{S}+\mathrm{CB}+\mathrm{N}=$ Control soil with corn residue biochar and $\mathrm{N}$ fertilizer; $\mathrm{S}+\mathrm{PB}=$ Control soil with pine bark biochar; $\mathrm{S}+\mathrm{PB}+\mathrm{N}=\mathrm{Control}$ soil with pine bark biochar and $\mathrm{N}$ fertilizer; $\mathrm{S}+\mathrm{N}+\mathrm{CPO}=$ Control soil with $\mathrm{N}$ fertilizer and calcium peroxide; $\mathrm{S}+\mathrm{N}+\mathrm{MPO}=\mathrm{Control}$ soil with $\mathrm{N}$ fertilizer and magnesium peroxide. Values in each column followed by similar letter are not statistically different from each other by Duncan Multiple Range Test at $P=0.05$.

days after incubation. For the control soil with pine bark biochar and $\mathrm{N}$ fertilizer $(\mathrm{S}+\mathrm{N}+\mathrm{PB})$, the peak rate was deferred by another two more days. All the OS treatments except two SOFs reached peak $\mathrm{N}_{2} \mathrm{O}$ production rate within only twenty-four hours of incubation invariably before starting diminishing. Evidently, the SOFs retarded peak $\mathrm{N}_{2} \mathrm{O}$ production rate attainment in OS. However, they did not reach the greater values of $\mathrm{S}+\mathrm{N}+\mathrm{PB}$ or $\mathrm{S}$ only, but rather retained the peak values for longer periods. The $\mathrm{S}+\mathrm{N}+\mathrm{MPO}$ had greatest $\mathrm{N}_{2} \mathrm{O}$ production rate after five days of incubation, which was eight days earlier than $\mathrm{S}+\mathrm{N}+\mathrm{CPO}$ 's peak $\mathrm{N}_{2} \mathrm{O}$ production rate.

Cumulative $\mathrm{N}_{2} \mathrm{O}$ production. For obvious reasons, cumulative $\mathrm{N}_{2} \mathrm{O}$ production was greater for all the treatments of OS than those of MS (Table 1; Figs. 3, 4), except the $\mathrm{CB}+\mathrm{N}$ treatments. The treatments with MS can be grouped in three distinctly different groups regarding cumulative $\mathrm{N}_{2} \mathrm{O}$ production over twenty-one days of incubation. The group comprised of lower $\mathrm{N}_{2} \mathrm{O}$ production rates included $\mathrm{S}, \mathrm{S}+\mathrm{CB}, \mathrm{S}+\mathrm{PB}, \mathrm{S}+\mathrm{N}+\mathrm{CPO}$ and $\mathrm{S}+\mathrm{N}+\mathrm{MPO}$ (Table 1). Even with $\mathrm{N}$ fertilizer, addition of SOFs (CPO and MPO) suppressed $\mathrm{N}_{2} \mathrm{O}$ production to the level of the treatments without $\mathrm{N}$ fertilizer. Substantively, soils with $\mathrm{N}$ and CPO resulted in the lowest total cumulative $\mathrm{N}_{2} \mathrm{O}$ production of $51 \mu \mathrm{g} \mathrm{N} \mathrm{N}_{2} \mathrm{~kg}^{-1}$ soil during the entire incubation period. It is also evident that presence of only biochar without $\mathrm{N}$ fertilizer failed to instigate $\mathrm{N}_{2} \mathrm{O}$ production compared to soil only. In 


\begin{tabular}{|l|l|r|}
\hline & CB & PB \\
\hline $\mathrm{pH}(1: 10)$ & 8.8 & 8.1 \\
\hline Total C (\%) & 42.7 & 44.8 \\
\hline Total N (\%) & 0.9 & 0.2 \\
\hline Total P (mg kg-1) & 39.6 & 61.6 \\
\hline \multicolumn{3}{|l|}{ Proximate analysis (\%) } \\
\hline Volatile matter & 30.2 & 22.2 \\
\hline Fixed C & 46.4 & 63.9 \\
\hline Ash & 23.4 & 13.9 \\
\hline
\end{tabular}

Table 2. Initial characteristics of corn residue (CB) and pine bark (PB) biochar.

contrast, addition of $\mathrm{N}$ fertilizer coupled with $\mathrm{CB}$ caused the greatest cumulative $\mathrm{N}_{2} \mathrm{O}$ production $\left(23,185 \mu \mathrm{gg} \mathrm{kg}^{-1}\right.$ $\mathrm{N}_{2} \mathrm{O}$ ) among all the treatments in MS. Pine (Pinus spp.) biochar along with $\mathrm{N}$ fertilizer application did not significantly increase total cumulative $\mathrm{N}_{2} \mathrm{O}$ production compared to $\mathrm{N}$ fertilizer-added soil. The differences among the treatments with $\mathrm{N}$ fertilizer in OS were not as distinct as in MS. The treatments without $\mathrm{N}$ fertilizer in OS, i.e. only S, $\mathrm{S}+\mathrm{CB}$, and $\mathrm{S}+\mathrm{CP}$, had cumulative $\mathrm{N}_{2} \mathrm{O}$ production of $12,027,8,980$, and $9,936 \mu \mathrm{g} \mathrm{kg}^{-1}$ soil. These values indicated significantly lower than those of the $\mathrm{N}$ fertilizer treatments (Table 1). In OS, the SOFs coupled with $\mathrm{N}$ fertilizer failed to suppress cumulative $\mathrm{N}_{2} \mathrm{O}$ production to the level of the treatments without $\mathrm{N}$ fertilizer. Rather, $\mathrm{S}+\mathrm{N}+\mathrm{MPO}(22,073 \mu \mathrm{g} \mathrm{kg}-1$ soil $)$ had similar cumulative $\mathrm{N}_{2} \mathrm{O}$ production to $\mathrm{S}+\mathrm{N}\left(23,757 \mu \mathrm{g} \mathrm{kg}^{-1}\right.$ soil $)$. Only, calcium peroxide with $\mathrm{N}$ fertilizer succeeded in reducing $\mathrm{N}_{2} \mathrm{O}$ production significantly less than $\mathrm{S}+\mathrm{N}$, but was comparable to $\mathrm{S}+\mathrm{CB}+\mathrm{N}$ or $\mathrm{S}+\mathrm{PB}+\mathrm{N}$.

Dynamics of mineral nitrogen. Figures 3 and 4 describe the pattern of mineral nitrogen $\left(\mathrm{NH}_{4}{ }^{+}\right.$and $\left.\mathrm{NO}_{3}{ }^{-}\right)$ in the MS and OS, respectively. In MS, the treatments were clearly segregated in producing mineral $\mathrm{N}$ based on the $\mathrm{N}$ fertilizer treatments. Soils without $\mathrm{N}$ fertilizer were trivial in mineral $\mathrm{N}$ content and range between 1.27 to $5.72 \mathrm{mg} \mathrm{NH}_{4}{ }^{+}$and $0.06-0.54 \mathrm{mg} \mathrm{NO}_{3}{ }^{-} \mathrm{kg}^{-1}$ soil. Soils with $\mathrm{N}$ fertilizer applied, except for the SOF treatments, were generally greater in $\mathrm{NH}_{4}{ }^{+}$content, ranging between $50-73 \mathrm{mg} \mathrm{kg}^{-1}$, whereas soils with $\mathrm{N}$ fertilizer and SOFs, contained 6-41 $\mathrm{mg} \mathrm{NH}_{4}^{+} \mathrm{kg}^{-1}$. For $\mathrm{NO}_{3}^{-}$, the upper limit for soils with $\mathrm{N}$ fertilizer with and without SOFs were ca. $75 \mathrm{mg} \mathrm{kg}^{-1}$ soil, while the lower limit was much lower for without SOFs (19-27 $\mathrm{mg} \mathrm{kg}^{-1}$ ) than with SOFs (52-57 mg kg-1 ). The $\mathrm{NO}_{3}{ }^{-}$content steadily decreased in soil with $\mathrm{N}$ fertilizer and without SOFs, however, soils with $\mathrm{N}$ fertilizer and SOFs maintained relatively greater $\mathrm{NO}_{3}{ }^{-}$levels during the incubation. In OS, irrespective of $\mathrm{N}$ fertilizer, soils without SOFs followed similar trends: greater concentration of $\mathrm{NO}_{3}^{-}\left(\sim 300 \mathrm{mg} \mathrm{kg}^{-1}\right.$ soil $)$ initially and lower concentration $\left(<20 \mathrm{mg} \mathrm{kg}^{-1}\right.$ soil $)$ at the end of the incubation. The $\mathrm{NH}_{4}{ }^{+}$concentration in those treatment soils increased on the $3^{\text {rd }}$ day of incubation compared to the beginning and was maintained $\left(\sim 100 \mathrm{mg} \mathrm{kg}{ }^{-1}\right.$ soil) for the rest of the incubation period. The trends of $\mathrm{NH}_{4}{ }^{+}$and $\mathrm{NO}_{3}^{-}$were similar for soil with $\mathrm{N}$ fertilizer and MPO to those soils without SOF, however, soil with $\mathrm{N}$ fertilizer and CPO showed different trends. The $\mathrm{NO}_{3}{ }^{-}$content in $\mathrm{S}+\mathrm{N}+\mathrm{CPO}$ decreased from $501 \mathrm{mg} \mathrm{kg}^{-1}$ soil at the beginning to only $225 \mathrm{mg} \mathrm{kg}^{-1}$ soil at the end of incubation while $\mathrm{NH}_{4}{ }^{+}$concentration was flattened for most of the period with a peak value of 122 on the 3rd day of incubation. It seems $\mathrm{NO}_{3}{ }^{-}$content was greater than $\mathrm{NH}_{4}{ }^{+}$for $\mathrm{S}+\mathrm{N}+\mathrm{CPO}$ at all sampling events while for rest of the treatment soils, $\mathrm{NH}_{4}{ }^{+}$concentration became greater than the $\mathrm{NO}_{3}{ }^{-}$content on the 3rd day of sampling and remained greater for the rest of the incubation.

Soil microbial biomass $\mathbf{C}$ and $\mathbf{N}$. Soil microbial biomass $\mathrm{C}$ and $\mathrm{N}$ in both soils were influenced by the application of biochar and SOFs with or without $\mathrm{N}$ fertilizer (Table 1). In mineral soils, PB with or without $\mathrm{N}$ fertilizer decreased MBC more than the control soil with or without $\mathrm{N}$ but not lower than the $\mathrm{CB}$ treated soils. Likewise, the soils with SOFs and $\mathrm{N}$ fertilizer also had lower MBC than the control soil with or without $\mathrm{N}$ fertilizer. The greatest MBN was recorded for $\mathrm{MS}$ in $\mathrm{S}+\mathrm{N}+\mathrm{CB}$, while the lowest being the soils treated with $\mathrm{N}$ fertilizer and SOFs. Similar to MS, SOFs decreased MBC and MBN in the OS soil as well. Surprisingly, CB application decreased $\mathrm{MBC}$ in OS but not the MBN compared to the control soil without $\mathrm{N}$. Thus, the impacts of biochar and SOFs, were variable considering both soils.

\section{Discussion}

The major source of $\mathrm{N}_{2} \mathrm{O}$ from agricultural soil has always been attributed to applied $\mathrm{N}$ fertilizer ${ }^{5}$. In this study, $\mathrm{N}$ fertilizer increased 74 times and 2 times of $\mathrm{N}_{2} \mathrm{O}$ production in MS and OS, respectively, thereby showing the importance of soil characteristics, besides $\mathrm{N}$ fertilizer. Presumably, the considerable difference in organic $\mathrm{C}$ content (33.9\% in OS and $1.2 \%$ in MS) has led to the distinct differences in $\mathrm{N}_{2} \mathrm{O}$ production. The major pathway of $\mathrm{N}_{2} \mathrm{O}$ production is heterotrophic denitrification by which $\mathrm{NO}_{3}{ }^{-}$is reduced by microorganisms and used as a terminal electron acceptor ${ }^{4}$. In heterotrophic denitrification, microorganisms use $\mathrm{C}$ as energy and electron sources $^{35}$. Thus, on average, OS produces more $\mathrm{N}_{2} \mathrm{O}$ given saturated moisture content than MS owing to its greater $\mathrm{C}$ content of OS. However, only two times increase in $\mathrm{N}_{2} \mathrm{O}$ in $\mathrm{OS}$ with $\mathrm{N}$ fertilizer than without $\mathrm{N}$ fertilizer compare to MS can be explained by following reasoning. Due to the greater $\mathrm{C}$ content and greater microbial biomass (Table 1) in OS, the heterotrophic $\mathrm{NO}_{3}{ }^{-}$reduction process could have continued till $\mathrm{N}_{2} \mathrm{O}$ production was not measured in the present investigation. In extremely anoxic condition due to greater microbial $\mathrm{O}_{2}$ demand or 

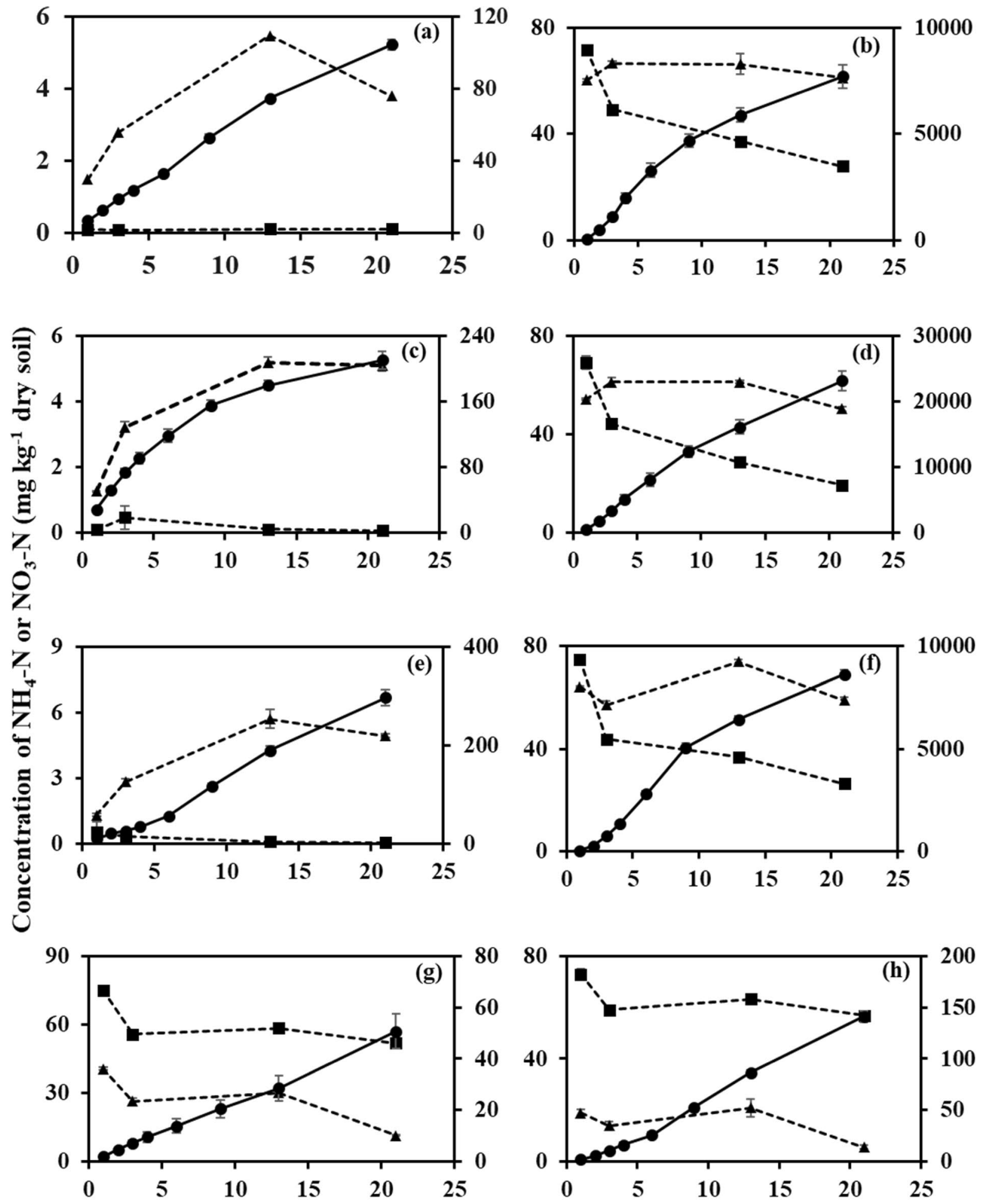

Days of incubation

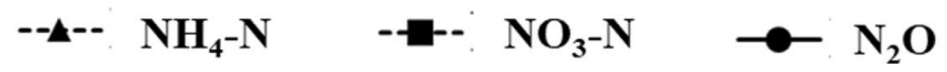

Figure 3. Cumulative $\mathrm{N}_{2} \mathrm{O}$ production, and mineral $\mathrm{N}$ concentration $\left(\mathrm{NH}_{4}{ }^{+}\right.$and $\left.\mathrm{NO}_{3}{ }^{-}\right)$in mineral soil (MS). $\mathrm{A}=$ Control soil only $(\mathrm{S}) ; \mathrm{b}=$ Control soil with $\mathrm{N}$ fertilizer $(\mathrm{S}+\mathrm{N}) ; \mathrm{c}=$ Control soil with corn residue biochar $(\mathrm{S}+\mathrm{CB}) ; \mathrm{d}=\mathrm{Control}$ soil with corn residue biochar and $\mathrm{N}$ fertilizer $(\mathrm{S}+\mathrm{CB}+\mathrm{N}) ; \mathrm{e}=\mathrm{Control}$ soil with pine bark biochar $(\mathrm{S}+\mathrm{PB}) ; \mathrm{f}=$ Control soil with pine bark biochar and $\mathrm{N}$ fertilizer $(\mathrm{S}+\mathrm{PB}+\mathrm{N})$; $\mathrm{g}=$ Control soil with $\mathrm{N}$ fertilizer and calcium peroxide $(\mathrm{S}+\mathrm{N}+\mathrm{CPO}) ; \mathrm{h}=\mathrm{Control}$ soil with $\mathrm{N}$ fertilizer and magnesium peroxide $(\mathrm{S}+\mathrm{N}+\mathrm{MPO})$. Bar represents standard error, $\mathrm{n}=3$. 

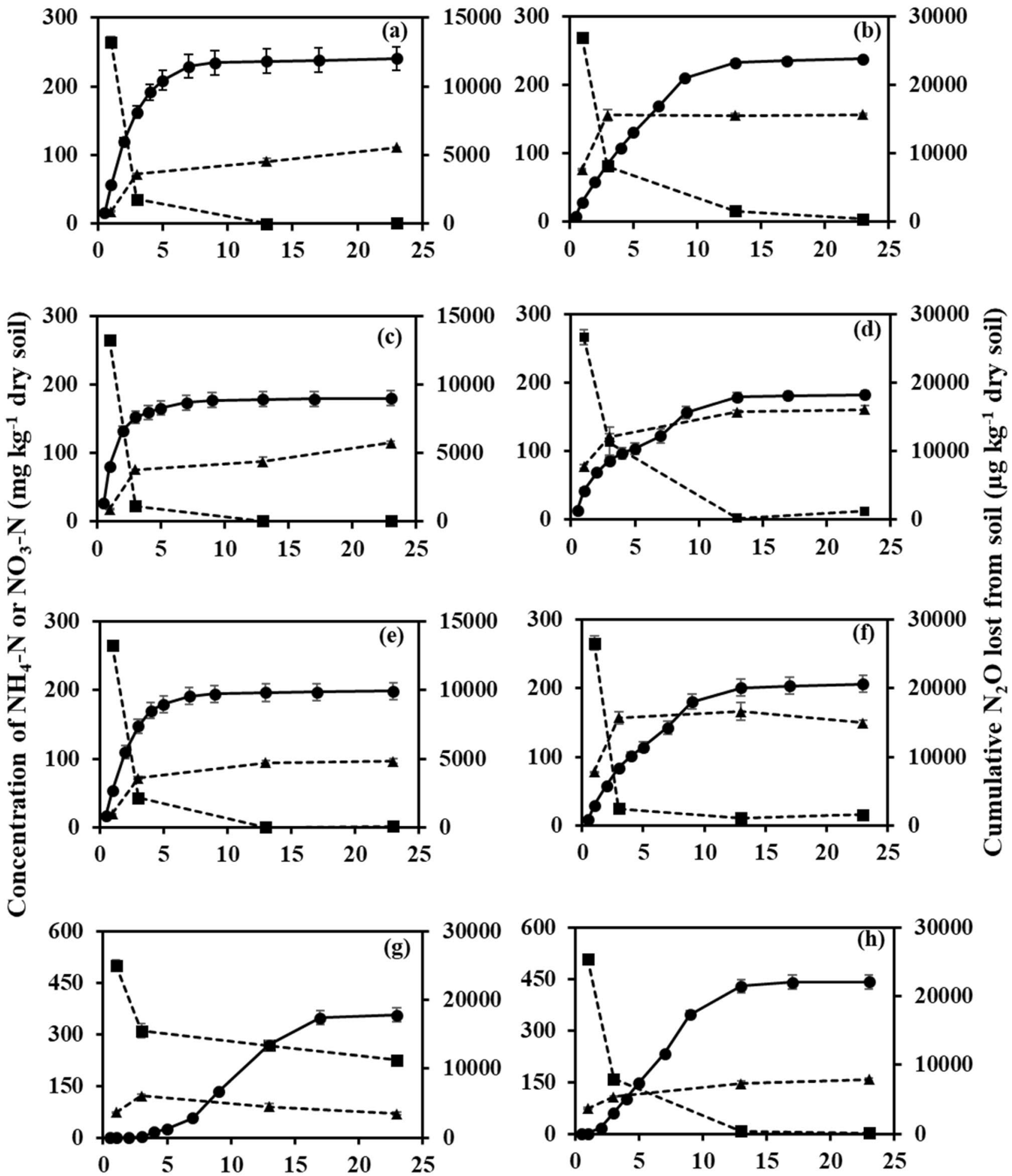

Days of incubation

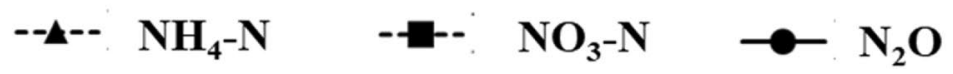

Figure 4. Cumulative $\mathrm{N}_{2} \mathrm{O}$ production, and mineral $\mathrm{N}$ concentration $\left(\mathrm{NH}_{4}{ }^{+}\right.$and $\left.\mathrm{NO}_{3}{ }^{-}\right)$in organic soil (OS). $\mathrm{A}=$ Control soil only $(\mathrm{S}) ; \mathrm{b}=\mathrm{Control}$ soil with $\mathrm{N}$ fertilizer $(\mathrm{S}+\mathrm{N}) ; \mathrm{c}=$ Control soil with corn residue biochar $(\mathrm{S}+\mathrm{CB}) ; \mathrm{d}=$ Control soil with corn residue biochar and $\mathrm{N}$ fertilizer $(\mathrm{S}+\mathrm{CB}+\mathrm{N})$; $\mathrm{e}=$ Control soil with pine bark biochar $(\mathrm{S}+\mathrm{PB}) ; \mathrm{f}=$ Control soil with pine bark biochar and $\mathrm{N}$ fertilizer $(\mathrm{S}+\mathrm{PB}+\mathrm{N})$; $\mathrm{g}=$ Control soil with $\mathrm{N}$ fertilizer and calcium peroxide $(\mathrm{S}+\mathrm{N}+\mathrm{CPO}) ; \mathrm{h}=\mathrm{Control}$ soil with $\mathrm{N}$ fertilizer and magnesium peroxide $(\mathrm{S}+\mathrm{N}+\mathrm{MPO})$. Bar represents standard error, $\mathrm{n}=3$. 


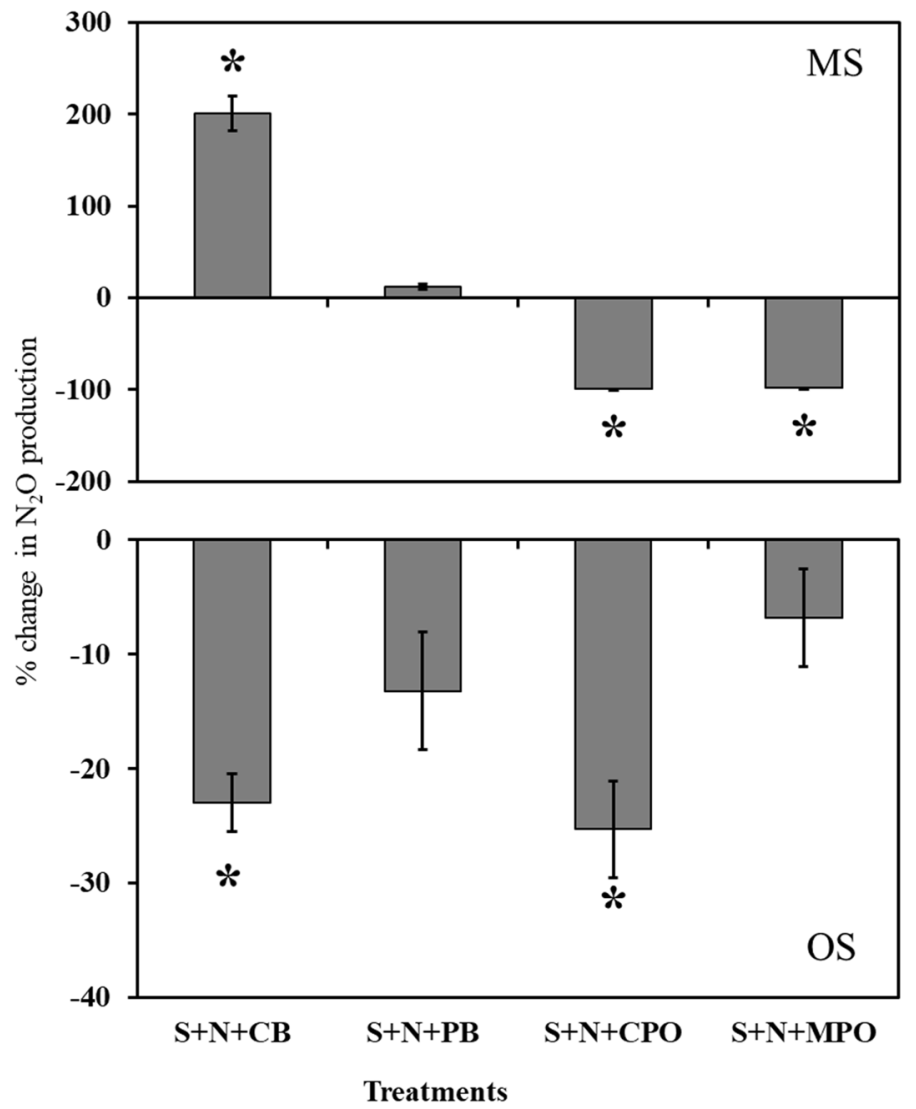

Figure 5. Percentage change in $\mathrm{N}_{2} \mathrm{O}$ production relative to soil with $\mathrm{N}$ fertilizer $(\mathrm{S}+\mathrm{N})$ only in mineral soil (MS) and in organic soil (OS). $\mathrm{S}+\mathrm{CB}+\mathrm{N}=$ Control soil with corn residue biochar and $\mathrm{N}$ fertilizer; $\mathrm{S}+\mathrm{PB}+\mathrm{N}=$ Control soil with pine bark biochar and $\mathrm{N}$ fertilizer; $\mathrm{S}+\mathrm{N}+\mathrm{CPO}=$ Control soil with $\mathrm{N}$ fertilizer and calcium peroxide; $\mathrm{S}+\mathrm{N}+\mathrm{MPO}=\mathrm{Control}$ soil with $\mathrm{N}$ fertilizer and magnesium peroxide. Bar represents standard error, $\mathrm{n}=3 .{ }^{*}$ Indicates significant difference from $\mathrm{S}+\mathrm{N}$ treatments in respective soil by Duncan Multiple Range Test at $P=0.05$.

prolonged water logging in soil, $\mathrm{NO}_{3}{ }^{-}$is reduced by heterotrophic denitrification to $\mathrm{N}_{2}{ }^{36}$. In the process, $\mathrm{N}_{2} \mathrm{O}$ as an intermediate product of heterotrophic denitrification, is being further reduced by microbes to use as the terminal electron acceptor. The importance of organic $\mathrm{C}$ in $\mathrm{N}_{2} \mathrm{O}$ production is also evident from the attainment time of peak $\mathrm{N}_{2} \mathrm{O}$ production rates in both soils. The almost instantaneous peak of $\mathrm{N}_{2} \mathrm{O}$ production rate in OS within a day of starting the experiment may be due to readily available $\mathrm{C}$ and $\mathrm{N}$ in OS. Conversely, organic C-lacking mineral soil took almost 3 days to attain peak $\mathrm{N}_{2} \mathrm{O}$ production rate except soil with CB. The difference in $\mathrm{N}_{2} \mathrm{O}$ production due to $\mathrm{N}$ fertilizer is also evident from the $\mathrm{NO}_{3}{ }^{-}$content of both soils with and without $\mathrm{N}$ fertilizer. In MS, $\mathrm{N}$ fertilizer increased $\mathrm{NO}_{3}{ }^{-}$content from $<1 \mathrm{mg} \mathrm{kg}^{-1}$ to $71 \mathrm{mg} \mathrm{kg}^{-1}$, while for OS there was no significant difference in $\mathrm{NO}_{3}{ }^{-}$content due to $\mathrm{N}$ fertilizer addition (Figs. 4, 5). Thus, increased availability of substrate in MS with $\mathrm{N}$ fertilizer led to a dramatic increase in $\mathrm{N}_{2} \mathrm{O}$ production despite of having low organic $\mathrm{C}$ content.

The effect of biochar on $\mathrm{N}_{2} \mathrm{O}$ production in both soils is contradictory considering the biochar and soil types (Fig. 5). In MS, CB might have provided some soluble organic $\mathrm{C}$ that might have acted as an energy source for soil microorganisms translating into such a greater $\mathrm{N}_{2} \mathrm{O}$ production with $\mathrm{N}$ fertilizer compared to soil with $\mathrm{N}$ fertilizer only. In the literature, volatile matter in biochar has been previously reported as a source of $\mathrm{C}$ for microorganisms ${ }^{37,38}$. Ameloot et al. showed a strong positive correlation between the easily mineralizable $\mathrm{C}$ pool and the volatile matter content of swine manure fermentation digestate and willow wood biochar with two different pyrolysis temperature $\left(350\right.$ and $\left.700{ }^{\circ} \mathrm{C}\right)$. The $\mathrm{PB}$ biochar effects can be similarly explained; however, the greater $\mathrm{N}_{2} \mathrm{O}$ production in soil with $\mathrm{N}$ fertilizer only indicates the importance of supply of $\mathrm{NO}_{3}{ }^{-}$that is the substrate of heterotrophic denitrification ${ }^{5}$. The supply of $\mathrm{NO}_{3}{ }^{-}$came from the applied $\mathrm{N}$ fertilizer in this present experiment as evidenced by the greater $\mathrm{NO}_{3}{ }^{-}$content in $\mathrm{N}$ fertilized MS soil (Fig. 4). Thus, for the greater $\mathrm{N}_{2} \mathrm{O}$ production from soil both the substrate, i.e. $\mathrm{NO}_{3}{ }^{-}$coming either from organic (soil amendments) or mineral ( $\mathrm{N}$ fertilizers) sources and the source of energy for microorganism, that is $\mathrm{C}$, is apparent ${ }^{4}$. However, the increased availability of organic $\mathrm{C}$ did not translate into greater soil microbial biomass for $\mathrm{S}+\mathrm{N}+\mathrm{CB}$ in MS, possibly indicating water logging stress. Given waterlogging with anoxic conditions, microbes showed greater respiration by increasing hydrogenase enzyme activity and metabolic quotient ${ }^{39,40}$. In this situation, microorganisms, which are facultative in nature, try to adjust with the new stressful environment by increasing respiration and losing $\mathrm{C}$ to the atmosphere rather than assimilating as biomass ${ }^{40}$. Thus, to continue profuse respiration, microbes use 
$\mathrm{NO}_{3}{ }^{-}$as a terminal electron acceptor in absence of molecular $\mathrm{O}_{2}$ in a waterlogged environment ${ }^{4}$. This fact is also supported by steep decreases in the $\mathrm{NO}_{3}{ }^{-}$concentration in $\mathrm{N}$ fertilized mineral soil without $\mathrm{SOF}$ and all the OS treatments in the present experiment. Contrarily, the profound effect of biochar is not that clear in OS. The OS is already well supplied with available organic $\mathrm{C}$ to microbes that the miniscule amount added through biochar is of less importance. Rather, ample availability of substrate for heterotrophic denitrification, i.e. $\mathrm{NO}_{3}{ }^{-}$added through $\mathrm{N}$ fertilizer, resulted in greater $\mathrm{N}_{2} \mathrm{O}$ production than soils without $\mathrm{N}$ fertilizer. However, in sharp contrast to mineral soil, $\mathrm{CB}$ significantly reducing $\mathrm{N}_{2} \mathrm{O}$ production in OS indicates the controlling mechanism is a result of unclear interaction between soil and biochar. Previously, many investigators have also reported transient effects of biochars on soil $\mathrm{N}_{2} \mathrm{O}$ production depending on soil and biochar properties ${ }^{29-32}$. Biochar ash content has been the other determining factor to regulate its impact on soil $\mathrm{N}_{2} \mathrm{O}$ emission though there is no general agreement on the underlying mechanism among the researchers. The conflicting effects of biochar volatile matter and ash contents on GHG emissions were multiplied by biochar-soil texture interaction that has produced widely varying effects on GHG emissions ${ }^{33}$. So, the present experiment including CB and PB with two distinct ash and volatile content results differently in two soil differing in $\mathrm{C}$ and texture. In both soils, biochar seems inconsequential in regulating the dynamics of mineral $\mathrm{N}$ as the concentrations of $\mathrm{NH}_{4}{ }^{+}$and $\mathrm{NO}_{3}{ }^{-}$are similar with or without biochar in $\mathrm{N}$ fertilized soil. In the literature, contrasting effects of biochar on $\mathrm{NO}_{3}{ }^{-}$and $\mathrm{NH}_{4}{ }^{+}$have been reported depending on biochar and soil properties in flooded or field capacity moisture conditions $\mathrm{s}^{41,42}$.

The impact of SOFs in reducing soil $\mathrm{N}_{2} \mathrm{O}$ production is not studied widely yet. The underlying mechanism of increasing bioavailable $\mathrm{O}_{2}$ under water stagnant conditions or in any aqueous solution is assumed to be based chemical equilibrium Eq. (1):

$$
\mathrm{MgO}_{2} / \mathrm{CaO}_{2}(\mathrm{~s})+2 \mathrm{H}_{2} \mathrm{O}(\mathrm{l}) \rightarrow \mathrm{Mg}(\mathrm{OH})_{2} / \mathrm{Ca}(\mathrm{OH})_{2}(\mathrm{~s})+\mathrm{H}_{2} \mathrm{O}_{2}(\mathrm{l})+\Delta \mathrm{H}
$$

The hydrogen peroxide from the above equilibrium, being unstable in normal temperatures, further decomposes to water and nascent oxygen. The nascent oxygen quickly forms $\mathrm{O}_{2}$ and becomes bioavailable to microbes or plant roots to take up for respiration as Eq. (2).

$$
2 \mathrm{H}_{2} \mathrm{O}_{2}(\mathrm{l}) \rightarrow 2 \mathrm{H}_{2} \mathrm{O}(\mathrm{l})+\mathrm{O}_{2}(\mathrm{~g})
$$

The decomposition of SOFs is determined by chemical equilibrium principles that in turn depend on the solubility of SOFs in water. In mineral soil, both SOFs significantly reduced $\mathrm{N}_{2} \mathrm{O}$ production, indicating that the amount applied was enough to provide ample $\mathrm{O}_{2}$ in waterlogged conditions to fulfill the requirements of microbial respiration. However, the inability of MPO to reduce $\mathrm{N}_{2} \mathrm{O}$ production in OS soil could be explained by the lower water solubility of MPO compared to CPO. The CPO $\left(1.65 \mathrm{~g} \mathrm{~L}^{-1}\right)$ has 19 times greater water solubility than MPO $\left(86 \mathrm{mg} \mathrm{L}^{-1}\right)$ at $20^{\circ} \mathrm{C}$. Organic soil, being greater in organic $\mathrm{C}$, inhabiting greater soil microbial biomass requires greater amount of oxygen than the mineral soil. Less soluble MPO failed to provide the required $\mathrm{O}_{2}$ resulting in a similar $\mathrm{N}_{2} \mathrm{O}$ production as soil with $\mathrm{N}$ fertilizer only. Similarly, both the SOFs in MS and CPO in OS maintaining greater $\mathrm{NO}_{3}{ }^{-}$level throughout the incubation period suggests that both SOFs were suitable for maintaining a greater oxygenated environment in MS. In OS, only CPO could maintain the same owing to its greater solubility, despite the greater $\mathrm{O}_{2}$ demand of $\mathrm{OS}$ microbes. Additionally, greater level of $\mathrm{NO}_{3}{ }^{-}$would pose a leaching problem if there is not any plant to uptake or soil is sandy in nature. However, $\mathrm{NO}_{3}{ }^{-}$leaching due to SOF is beyond the scope of current investigation to discuss.

The only point of concern is the reduction of microbial biomass in both MS and OS soils with N fertilizer and SOFs. The drastic decrease in microbial biomass in SOF treatments could also be from the possible heat and increased $\mathrm{pH}^{43}$. Dissociation of SOFs is an exothermic reaction resulting in increased soil $\mathrm{pH}$ of the medium due to formation of hydroxide ${ }^{43}$. At the end of experiment, mineral soil $\mathrm{pH}$ measured between 9.80 and 10.00 for $\mathrm{CPO}$ and MPO would validate the reasoning. For organic soil moderate pH change (8.25-8.35) would indicate the greater buffering capacity of organic soil than mineral soil thus having lesser impact on microbial biomass. However, the application of SOFs has been successful in alleviating hypoxic stress in corn and Italian basil ${ }^{14,34}$ even though it may increase the $\mathrm{pH}$. Besides, in the present study, SOFs maintained greater levels of available $\mathrm{NO}_{3}{ }^{-}$in flooded conditions supplying ready availability of $\mathrm{N}$ to plant roots. Apparently, the immediate harmful effects of SOFs on plant production is negligible if there is any.

\section{Conclusions}

Nitrous oxide emission is a serious concern for human health, agriculture, and the environment worldwide. Findings from our study indicate that $\mathrm{N}$ fertilization of mineral soils is potentially more prone to increased $\mathrm{N}_{2} \mathrm{O}$ production. This is contrary to the general norm that organic soil tend to have higher $\mathrm{N}_{2} \mathrm{O}$ production than mineral soil. Both solid oxygen fertilizers in mineral soil and calcium peroxide in organic soil were successful in reducing $\mathrm{N}_{2} \mathrm{O}$ production while maintaining greater levels of $\mathrm{NO}_{3}{ }^{-}$. The corn residue biochar with $\mathrm{N}$ fertilizer increased $\mathrm{N}_{2} \mathrm{O}$ production in mineral soils but decreased production in organic soil. Pine bark biochar with $\mathrm{N}$ did not escalate in either of the soils indicating the mixed response of biochar on $\mathrm{N}_{2} \mathrm{O}$ production depending on biochar and soil type. Thus, depending on the soil, different types of solid oxygen fertilizers may be applied to alleviate hypoxic stress, decrease $\mathrm{N}_{2} \mathrm{O}$ production, and maintain plant available $\mathrm{NO}_{3}{ }^{-}$in soil in hypoxic conditions. These findings provide a basis for future long-term laboratory incubation or field studies with different soil types and solid oxygen fertilizer rates to formulate an effective solid oxygen fertilizer technology for adaptation by growers. 


\begin{tabular}{|l|l|l|}
\hline & MS & OS \\
\hline $\mathrm{pH}(1: 2)$ & 6.3 & 6.9 \\
\hline Texture & Sand & Sandy clay loam \\
\hline Sand (\%) & 98.8 & 56.0 \\
\hline Silt (\%) & 0.8 & 18.4 \\
\hline Clay (\%) & 0.4 & 25.6 \\
\hline Maximum water holding capacity (\%) & 22 & 128 \\
\hline Total C (\%) & 1.2 & 33.9 \\
\hline Total $\mathrm{N}(\%)$ & 0.72 & 3.6 \\
\hline Mehlich-1 $\mathrm{P}\left(\mathrm{kg} \mathrm{ha}^{-1}\right)$ & 50 & 75 \\
\hline Mehlich-1 K $\left(\mathrm{kg} \mathrm{ha}^{-1}\right)$ & 20 & 894 \\
\hline Mehlich-1 Ca $\left(\mathrm{kg} \mathrm{ha}^{-1}\right)$ & 529 & 9403 \\
\hline Mehlich-1 Mg $\left(\mathrm{kg} \mathrm{ha}^{-1}\right)$ & 42 & 1560 \\
\hline CEC (meq $100 \mathrm{~g} \mathrm{~g}^{-1}$ soil) & 2.2 & 31.8 \\
\hline
\end{tabular}

Table 3. Initial physico-chemical properties of mineral (MS) and organic (OS) soil.

\section{Materials and methods}

Soils, biochars and solid oxygen fertilizers. Two soils differing in organic matter content and texture were used for this laboratory experiment. Mineral soil with $1.2 \%$ organic C, Kanapaha fine sand, (loamy, siliceous, semi-active hyperthermic Grossarenic Paleaquult) ${ }^{44}$ was collected from UF/IFAS Plant Science Research and Education Unit, Citra (29 $\left.24^{\prime} \mathrm{N} 82^{\circ} 08^{\prime} \mathrm{W}\right)$. Organic soil with $33.9 \%$ organic C (Pahokee Muck, hyperthermic Lithic Haplosaprists $)^{45}$ was collected from UF/IFAS Everglades Research and Education Center, Belle Glade $\left(26^{\circ}\right.$ $\left.39^{\prime} \mathrm{N} 80^{\circ} 37^{\prime} \mathrm{W}\right)$. Ultisols ( 2.8 million ha) and Histosols ( $\sim 1.6$ million ha) are major soil groups that support Florida's agriculture (valued $\$ 104$ billion yearly), including vegetable and sugarcane production ${ }^{46}$. The soils were brought to the laboratory in the Horticultural Sciences Department at University of Florida (UF), Gainesville, Florida, USA. The sampled bulk soil was homogenized, passed through a 2-mm sieve, and stored in polyethylene containers at $-4{ }^{\circ} \mathrm{C}$ until start of the incubation experiments. Initial physico-chemical properties of both soils are presented in Table 3.

Two biochars were produced from two different feedstocks viz. corn residues and pine bark through a slow pyrolysis process in a cast iron kiln in an electric furnace at the Agriculture and Biological Engineering Department, UF, Gainesville, FL. Both residue feedstocks were chopped into small pieces $(\sim 2 \mathrm{~cm}$ in length) and sun dried to a constant moisture content before pyrolysis. Feedstocks were pyrolyzed slowly with temperature increasing at a rate of $10^{\circ} \mathrm{C} \mathrm{min}{ }^{-1}$ until $550{ }^{\circ} \mathrm{C}$ and kept at that temperature for $4 \mathrm{~h}$. Subsequently, the pyrolyzing reactor was left to cool in natural conditions overnight. Two biochars (CB-corn biochar, PB-pine bark biochar) were then oven-dried at $65^{\circ} \mathrm{C}$, crushed, sieved $(2-\mathrm{mm})$, and stored in polyethylene containers at room temperature until further use. The initial properties of biochar are presented in Table 2.

The SOFs used in this experiment were calcium peroxide $\left(\mathrm{CaO}_{2}, \mathrm{CPO}\right)$ and magnesium peroxide $\left(\mathrm{MgO}_{2}\right.$, MPO), provided by Solvary Interox, Inc. (Houston, TX, USA). Calcium peroxide is a pale yellow, odorless powder with a solubility of $1.65 \mathrm{~g} \mathrm{~L}^{-1}$ at $20^{\circ} \mathrm{C}$ and $\mathrm{pH}$ of $11.7 \mathrm{of} 1 \%$ aqueous suspension. Magnesium peroxide is a white odorless powder with solubility of $86 \mathrm{mg} \mathrm{L}^{-1}$ and $\mathrm{pH}$ of 10.3 of $1 \%$ aqueous suspension.

Laboratory incubation experiments. Two laboratory incubation experiments were conducted

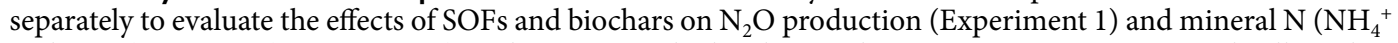
and $\mathrm{NO}_{3}{ }^{-}$) contents (Experiment 2 ) in these two studied soils. Conducting experiment 2 separately allowed us to sample soil destructively for mineral $\mathrm{N}$ determination without affecting $\mathrm{N}_{2} \mathrm{O}$ production. Both experiments were conducted simultaneously at constant temperature $\left(23-25^{\circ} \mathrm{C}\right)$ during March-April 2017. The treatments for experiments were: Control soil without nitrogen $(S)$ and with $224 \mathrm{~kg} \mathrm{~N} \mathrm{ha}^{-1}$ through ammonium nitrate $(33.5 \% \mathrm{~N})(\mathrm{S}+\mathrm{N})$; soil with $\mathrm{CB}$ without $\mathrm{N}(\mathrm{S}+\mathrm{CB})$ and with $\mathrm{N}(\mathrm{S}+\mathrm{CB}+\mathrm{N})$; soil with $\mathrm{PB}$ without $\mathrm{N}(\mathrm{S}+\mathrm{PB})$ and with $\mathrm{N}(\mathrm{S}+\mathrm{PB}+\mathrm{N})$; soil with $\mathrm{N}$ with either $\mathrm{CPO}(\mathrm{S}+\mathrm{CPO}+\mathrm{N})$ or $\mathrm{MPO}(\mathrm{S}+\mathrm{MPO}+\mathrm{N})$. In total, there were 48 incubation units, including two soils $\times$ eight treatments replicated three times. The SOFs and biochar were applied at the rate of $0.5 \%(\mathrm{w} / \mathrm{w})$. For experiment $1,100 \mathrm{~g}$ of MS and $50 \mathrm{~g}$ of OS soil were mixed with respective treatments and incubated for ca. three weeks in loosely covered, wide-mouth mason jars $\left(473 \mathrm{~cm}^{3}\right)$ in darkness on a laboratory bench top. For experiment 2, four incubation units consisting of $75 \mathrm{~g}$ of MS or $37.5 \mathrm{~g}$ of OS were maintained separately to have $300 \mathrm{~g}$ of MS and $150 \mathrm{~g}$ of OS in total for a single replication of an individual treatment. Before starting incubation, soil and biochar for respective treatments were mixed to a uniform blend and moistened with distilled water to $60 \%$ of the maximum water holding capacity (MWHC). At this stage, units were incubated for three days to eliminate the disturbances due to sampling, processing, and storing. At the start of the experiment a nitrogen fertilizer solution made from ammonium nitrate $(33.5 \% \mathrm{~N})$ and extra distilled water was added to make up moisture content to $100 \%$ of MWHC of two soils. During the experiment, incubation units were periodically checked for evaporative water loss and distilled water was added through micropipette in an event of any moisture loss detected. For experiment $1, \mathrm{~N}_{2} \mathrm{O}$ was measured at pre-determined intervals that were more frequent in OS $(0.5,1,2,3,4,5,7,9,13,17$ and 23 days of incubation) than MS $(1,2$, $3,4,6,9,13$ and 21 days of incubation). For each soil sampling event $(1,3,13$ and 21 or 23 days of incubation 
for MS or OS, respectively), $25 \mathrm{~g}$ of moist soil were destructively sampled from each incubation unit for mineral $\mathrm{N}$ analysis in Experiment 2. At the end of incubation, last sampling soils were used to determine soil microbial biomass $\mathrm{C}$ and $\mathrm{N}$ in respective treatments for both soils.

Soil, biochar, $\mathrm{N}_{2} \mathrm{O}$ and microbial biomass analysis. Soil $\mathrm{pH}$ was measured in a 1:2 soil to distilled water ratio. Soil total $\mathrm{C}$ and $\mathrm{N}$ content were analyzed by dry combustion in a Thermo Flash EA 1112 elemental analyzer (CE Elantech Inc., Lakewood, NJ, USA) ${ }^{22}$. Extractable phosphorus, potassium, calcium, and manganese were extracted with Mehlich-1 extractant followed by determination in inductively coupled plasma spectrophotometry (ICP-AES). Texture, maximum water holding capacity, and cation exchange capacity of soil were measured following standard procedure. Mineral $\mathrm{N}\left(\mathrm{NH}_{4}{ }^{+}\right.$and $\left.\mathrm{NO}_{3}{ }^{-}\right)$of soils was extracted with $2 \mathrm{~mol} \mathrm{~L}^{-1}$ $\mathrm{KCl}$ and measured using a discreate flow autoanalyzer AQ2 (SEAL Analytical Inc. Mequon, Wisconsin). Biochar $\mathrm{pH}$, total $\mathrm{C}$ and $\mathrm{N}$ were measured similar to soil with exception of the biochar ratio: water $(1: 10)$ ratio. Total $\mathrm{P}$ was measured after acid digestion followed by ICP-AES determination. Proximate analysis of biochar was conducted following the procedure of Bera et al ${ }^{47}$. Nitrous oxide release was measured using gas chromatograph (GC-2014, Shimadzu USA) equipped with electron capture detector to measure $\mathrm{N}_{2} \mathrm{O}$ equipped with electron capture detector. At each sampling, a jar containing the sample was tightly capped for $12 \mathrm{~h}$. After that, a 1-mL syringe was used to draw the air from the jar, and the sample was directly injected in the GC. Soil microbial biomass $\mathrm{C}$ and $\mathrm{N}$ were measured following standard procedure of chloroform fumigation and $0.5 \mathrm{M}$ potassium sulfate extraction ${ }^{48}$.

Data calculation and Statistical analysis. At each sampling, $\mathrm{N}_{2} \mathrm{O}$ concentration was calculated using the universal gas law and then dividing the concentration by $12 \mathrm{~h}$ to get the rate ${ }^{49}$. Cumulative $\mathrm{N}_{2} \mathrm{O}$ concentrations were estimated by linear interpolation of the hourly $\mathrm{N}_{2} \mathrm{O}$ concentration rate at each sampling event for each treatment in each soil. Both experiments were conducted as completely randomized design. To determine the treatment effects, data were analyzed using one-way analysis of variance in PROC ANOVA (SAS, 2015, SAS Institute Inc., Cary, NC, USA $)^{50}$. The multiple mean separation with corresponding letter grouping method was performed using Duncan's Multiple Range Test (DMRT) at a significance level of 5\% in SAS.

\section{Data availability}

The datasets generated during and/or analyzed during the current study are available from the corresponding author on reasonable request.

Received: 28 July 2020; Accepted: 22 October 2020

Published online: 10 December 2020

\section{References}

1. Forster, P. et al. Changes in atmospheric constituents and in radiative forcing. Chapter 2. In Climate Change 2007. The Physical Science Basis. (Cambridge University Press, 2007).

2. World Meteorological Organization. The State of Greenhouse Gases in the Atmosphere Based on Global Observation through 2017. WMO Greenhouse Gas Bulletin No. 14. https://library.wmo.int/doc_num.php?explnum_id=5455 (2018).

3. Anderson, B., et al. Methane and nitrous oxide emissions from natural sources, Office of Atmospheric Programs, US EPA. EPA 430-R-10-001, Washington DC (2010).

4. Bremner, J. M. Sources of nitrous oxide in soils. Nutr. Cycl. Agroecosyst. 49, 7-16 (1997).

5. Brentrup, F., Küsters, J., Lammel, J. \& Kuhlmann, H. Methods to estimate on-field nitrogen emissions from crop production as an input to LCA studies in the agricultural sector. Int. J. Life Cycle Assess. 5, 349 (2000).

6. Snyder, C. S., Bruulsema, T. W., Jensen, T. L. \& Fixen, P. E. Review of greenhouse gas emissions from crop production systems and fertilizer management effects. Agric. Ecosyst. Environ. 133, 247-266 (2009).

7. Enanga, E. M., Creed, I. F., Casson, N. J. \& Beall, F. D. Summer storms trigger soil $\mathrm{N}_{2} \mathrm{O}$ efflux episodes in forested catchments. J. Geophys. Res. Biogeo. 121, 95-108 (2016).

8. Stewart, D. J., Taylor, C. M., Reeves, C. E. \& Mcquaid, J. B. Biogenic nitrogen oxide emissions from soils: Impact on NOx and ozone over West Africa during AMMA (African Monsoon Multidisciplinary Analysis): Observational study. Atmos. Chem. Phys. Eur. Geosci. Union 8, 2285-2297 (2008).

9. Kralova, M., Masscheleyn, P. H., Lindau, C. W. \& Patrick, W. H. Jr. Production of dinitrogen and nitrous oxide in soil suspensions as affected by redox potential. Water Air Soil Poll. 61, 37-45 (1992).

10. Davidsson, T. E. \& Ståhl, M. The influence of organic carbon on nitrogen transformations in five wetland soils. Soil Sci. Soc. Am. J. 64, 1129-1136 (2000).

11. Groffman, P. M. et al. Challenges to incorporating spatially and temporally explicit phenomena (hotspots and hot moments) in denitrification models. Biogeochemistry 93, 49-77 (2009).

12. Vidon, P. et al. Hot spots and hot moments in riparian zones: Potential for improved water quality management ${ }^{1}$. J Am. Water Resour. As. 46, 278-298 (2010).

13. Vidon, P., Jacinthe, P.-A., Liu, X., Fisher, K. \& Baker, M. Hydrobiogeochemical controls on riparian nutrient and greenhouse gas dynamics: 10 years post-restoration. J Am. Water Resour. As. 50, 639-652 (2014).

14. Liu, G., Li, Y., Migliaccio, K., Olczyk, T. \& Alva, A. Oxygen amendment on growth and nitrogen use efficiency of flooded Italian basil. Int. J. Veg. Sci. 19, 217-227 (2013).

15. Liu, G., Li, Y. \& Fu, X. (SL206) Practices to minimize flooding damage to commercial vegetable production. https://edis.ifas.ufl. edu/ss425 (2019).

16. Li, C., Frolking, S. \& Frolking, T. A. A model of nitrous oxide evolution from soil driven by rainfall events: 1. Model structure and sensitivity. J. Geophys. Res. Atmos. 97, 9759-9776 (1992).

17. Roque-Malo, S. \& Kumar, P. Patterns of change in high frequency precipitation variability over North America. Sci. Rep. 7, 10853. https://doi.org/10.1038/s41598-017-10827-8 (2017).

18. Corradi, R., M., Lambert, F., Ramirez-Villegas, J. \& Challinor, A. Climate change affects rainfall patterns in crop-producing regions: Findings from the study "Emergence of robust precipitation changes across crop production areas in the 21st century". In CCAFS Info Note. Wageningen, Netherlands: CGIAR Research Program on Climate Change, Agriculture and Food Security (CCAFS) (2019). 
19. Liu, G., et al. 2020-2021 Vegetable Production Handbook: Chapter 2. Fertilizer Management for Vegetable Production in Florida. https://edis.ifas.ufl.edu/cv296 (2020).

20. Lehmann, J., Gaunt, J. \& Rondon, M. Bio-char Sequestration in Terrestrial Ecosystems - A Review. Mitig. Adapt. Strat. GL. 11, 403-427 (2006).

21. Lehmann, J. \& Joseph, S. Biochar for environmental management: An introduction. In Biochar for Environmental Management: Science, Technology, and Implementation (ed. Lehmann, J. \& Joseph, S.) 33-46. (Routledge, 2015).

22. Bera, T., Collins, H. P., Alva, A. K., Purakayastha, T. J. \& Patra, A. K. Biochar and manure effluent effects on soil biochemical properties under corn production. Appl. Soil Ecol. 107, 360-367 (2016).

23. Bera, T. et al. Influence of select bioenergy by-products on soil carbon and microbial activity: A laboratory study. Sci. Total Environ. 653, 1354-1363 (2019).

24. Purakayastha, T. J. et al. A review on biochar modulated soil condition improvements and nutrient dynamics concerning crop yields: Pathways to climate change mitigation and global food security. Chemosphere 227, 345-365 (2019).

25. Zimmerman, A. R. Abiotic and microbial oxidation of laboratory-produced black carbon (biochar). Environ. Sci. Technol. 44, 1295-1301 (2010).

26. Woolf, D., Amonette, J., Street-Perrott, F., Lehmann, J. \& Joseph, S. Sustainable biochar to mitigate global climate change. Nat. Commun. 1, 56 (2010).

27. Mukherjee, A., Lal, R. \& Zimmerman, A. R. Effects of biochar and other amendments on the physical properties and greenhouse gas emissions of an artificially degraded soil. Sci. Total Environ. 487, 26-36 (2014).

28. Lan, Z. M., Chen, C. R., Rashti, R. M., Yang, H. \& Zhang, D. K. Stoichiometric ratio of dissolved organic carbon to nitrate regulates nitrous oxide emission from the biochar-amended soils. Soil Sci. Plant Nutr. 576, 559-571 (2017).

29. Yanai, Y., Toyota, K. \& Okazaki, M. Effects of charcoal addition on $\mathrm{N}_{2} \mathrm{O}$ emissions from soil resulting from rewetting air-dried soil in short-term laboratory experiments. Soil Sci. Plant Nutr. 53, 181-188 (2007).

30. Clough, T. J. et al. Unweathered wood biochar impact on nitrous oxide emissions from a bovine-urine-amended pasture soil. Soil Sci. Soc. Am. J. 74, 852-860 (2010).

31. Singh, B. P. et al. Influence of biochars on nitrous oxide emission and nitrogen leaching from two contrasting soils. J. Environ. Qual. 39, 1224-1235 (2010).

32. Cayuela, M. L. et al. Biochar's role in mitigating soil nitrous oxide emissions: A review and meta-analysis. Agric. Ecosyst. Environ. 191, 5-16 (2014).

33. Cayuela, M. L. et al. Biochar and denitrification in soils: When, how much and why does biochar reduce $\mathrm{N}_{2} \mathrm{O}$ emissions?. Sci. Rep. 3, 1732 (2013).

34. Liu, G. \& Porterfield, D. M. Oxygen enrichment with magnesium peroxide for minimizing hypoxic stress of flooded corn. J. Plant Nutr. Soil Sci. 177, 733-740 (2014).

35. Brady, N. C. \& Weil, R. R. The Nature and Properties of Soils 1-187 (Prentice-Hall Inc., Upper Saddle River, 1999).

36. Weier, K. L., Doran, J. W., Power, J. F. \& Walters, D. T. Denitrification and the dinitrogen/nitrous oxide ratio as affected by soil water, available carbon, and nitrate. Soil Sci. Soc. Am. J. 57, 66-72 (1993).

37. Ameloot, N. et al. Short-term $\mathrm{CO}_{2}$ and $\mathrm{N}_{2} \mathrm{O}$ emissions and microbial properties of biochar amended sandy loam soils. Soil Biol. Biochem. 57, 401-410 (2013).

38. Spokas, K. A. et al. Qualitative analysis of volatile organic compounds on biochar. Chemosphere 85, 869-882 (2011).

39. Chendrayan, K., Adhya, T. K. \& Sethunathan, N. Dehydrogenase and invertase activities of flooded soils. Soil Biol. Biochem. 12, 271-273(1980).

40. Macé, O. G., Steinauer, K., Jousset, A., Eisenhauer, N. \& Scheu, S. Flood-induced changes in soil microbial functions as modified by plant diversity. PLoS ONE 11(11), e0166349. https://doi.org/10.1371/journal.pone.0166349 (2016).

41. van Zwieten, L. et al. Influence of biochars on flux of $\mathrm{N}_{2} \mathrm{O}$ and $\mathrm{CO}_{2}$ from Ferrosol. Aust. J. Soil Res. 48, 555-568 (2010).

42. Zheng, J., Stewart, C. E. \& Cotrufo, F. M. Biochar and nitrogen fertilizer alters soil nitrogen dynamics and greenhouse gas fluxes from two temperate soils. J. Environ. Qual. 41, 1361-1370 (2012).

43. Lu, S., Zhang, X. \& Xue, Y. Application of calcium peroxide in water and soil treatment: A review. J. Hazard. Mater. 337, 163-177 (2017).

44. Reyes-Cabrera, J. et al. Amending marginal sandy soils with biochar and lignocellulosic fermentation residual sustains fertility in elephantgrass bioenergy cropping systems. Nutr. Cycl. Agroecosyst. 115, 69-83 (2019).

45. Zobeck, T. M. et al. Soil property effects on wind erosion of organic soils. Aeolian Res. 10, 43-51 (2013).

46. Collins, M. E. Key to soil orders in Florida. University of Florida Cooperative Extension Service, Institute of Food and Agriculture Sciences, EDIS (2009)

47. Bera, T., Purakayastha, T. J., Patra, A. K. \& Datta, S. C. Comparative analysis of physicochemical, nutrient, and spectral properties of agricultural residue biochars as influenced by pyrolysis temperatures. J. Mater. Cycles Waste 20, 1115-1127 (2018).

48. Vance, E. D., Brookes, P. C. \& Jenkinson, D. S. Microbial biomass measurements in forest soils: The use of the chloroform fumigation-incubation method in strongly acid soils. Soil Biol. Biochem. 19, 697-702 (1987).

49. Butnan, S., Deenik, J. L., Toomsan, B. M., Antal, J. \& Vityakon, P. Biochar properties influencing greenhouse gas emissions in tropical soils differing in texture and mineralogy. J. Environ. Qual. 45, 1509-1519 (2016).

50. SAS Institute Inc. Base SAS 9.4 Procedures Guide, 5th ed. SAS Institute Inc., Cary (2015).

\section{Acknowledgements}

Our colleagues, Dr. J. Bhadha, Mr. William Nelson, and Mr. Xiangju Fu helped collect soil; Dr. Edward Hanlon, Miss Mary Dixon, and Mr. Jonathan Denison at the University of Florida, reviewed the manuscript.

\section{Author contributions}

G.D.L., T.B. and K.S.I. conceptualized the experiments. T.B. conducted the experiments, analyzed the data, and wrote first draft of the manuscript. All authors subsequently contributed to editing and improving the final manuscript.

\section{Competing interests}

The authors declare no competing interests.

Additional information

Correspondence and requests for materials should be addressed to G.D.L.

Reprints and permissions information is available at www.nature.com/reprints. 
Publisher's note Springer Nature remains neutral with regard to jurisdictional claims in published maps and institutional affiliations.

(c) (i) Open Access This article is licensed under a Creative Commons Attribution 4.0 International License, which permits use, sharing, adaptation, distribution and reproduction in any medium or format, as long as you give appropriate credit to the original author(s) and the source, provide a link to the Creative Commons licence, and indicate if changes were made. The images or other third party material in this article are included in the article's Creative Commons licence, unless indicated otherwise in a credit line to the material. If material is not included in the article's Creative Commons licence and your intended use is not permitted by statutory regulation or exceeds the permitted use, you will need to obtain permission directly from the copyright holder. To view a copy of this licence, visit http://creativecommons.org/licenses/by/4.0/.

This is a U.S. Government work and not under copyright protection in the US; foreign copyright protection may apply 2020 